\title{
A laboratory method to evaluate the sensitivity of Colletotrichum musae to postharvest fungicides
}

\author{
Luc de Lapeyre de Bellaire ${ }^{1}$, Yolande Chilin-Charles ${ }^{2}$
}

${ }^{1}$ CIRAD, Persyst, UPR Systèmes bananes et ananas, CARBAP, BP 832, Douala, Cameroon

luc.de_lapeyre_de_bellaire @cirad.fr

2 CIRAD, Bios, UPR

Multiplication végétative,

Station de Neufchâteau,

97130, Capesterre Belle-Eau, Guadeloupe, France

yolande.chilin-charles@cirad.fr
${ }^{*}$ Correspondence and reprints

Fruits, 2008, vol. 63, p. 263-266

(C) 2008 Cirad/EDP Sciences

All rights reserved

DOI: $10.1051 /$ fruits:2008021

www.fruits-journal.org

\section{A laboratory method to evaluate Colletotrichum musae's sensitivity to thiabendazole and SBI fungicides.}

Abstract - Introduction. This protocol aims at detecting and evaluating sensitivity shifts in Colletotrichum musae populations towards fungicides that are currently used for the control of postharvest diseases of bananas. The principle, key advantages, starting plant material, time required and expected results are presented. Materials and methods. The necessary laboratory materials and details of the twelve steps of the protocol for banana sampling and anthracnose lesion development, the agar plate preparation, single-spore isolation, germination test, and data analysis are described. Possible troubleshooting is mentioned. We obtain (a) for antimitotic products, the percentage of resistant strains in the population analysed; (b) for Sterol Biosynthesis Inhibitor (SBI) fungicides, the variation and distribution of the isolates' sensitivity within the population analysed according to their level of radial growth reduction by the fungicide.

France (Guadeloupe) / Musa sp. / chemical control / methods / Colletotrichum musae / resistance to chemicals

\section{Une méthode de laboratoire pour évaluer la sensibilité de Colletotrichum musae aux fongicides utilisés en traitement après récolte.}

Résumé - Introduction. Ce protocole vise à détecter et évaluer des variations de sensibilité dans des populations de Colletotrichum musae vis-à-vis des fongicides actuellement utilisés pour le contrôle des maladies de conservation des bananes. Le principe, les principaux avantages, le matériel végétal de départ, le temps nécessaire et les résultats attendus de la méthode sont présentés. Matériel et méthodes. Le matériel de laboratoire nécessaire, et le détail des douze étapes du protocole réalisé pour l'échantillonnage des bananes et le développement des lésions dues à l'anthracnose, la préparation des boites de milieu gélosé (agar), les isolements monospores, les tests de germination et l'analyse des données sont décrits. De possibles problèmes sont évoqués. Nous obtenons (a) pour les produits antimitotiques, le pourcentage de souches résistantes dans la population analysée ; (b) pour des fongicides inhibiteurs de la biosynthèse des stérols (SBI), la variation et la distribution de la sensibilité des isolats dans la population analysée en fonction de la réduction de leur croissance radiale, imputable au fongicide.

France (Guadeloupe) / Musa sp. / lutte chimique / méthode / Colletotrichum musae / résistance aux produits chimiques

\section{Introduction}

\section{Application}

This protocol aims at detecting and evaluating sensitivity shifts in Colletotrichum musae populations towards fungicides that are currently used to control postharvest diseases of bananas.

\section{Principle}

Heavy conidiogenesis is induced on anthracnose lesions of fruits, in order to make 
single-spore isolations. For each strain, the radial growth of the colony is compared on fungicide-amended and non-amended media. The sensitivity of strains from sprayed areas is compared with the sensitivity of reference wild strains that have never been exposed to the fungicide. This method has already been described by de Lapeyre de Bellaire and Dubois in 1997 [1]

\section{Key advantage}

Other methods used for the monitoring of resistance in fungal populations focus on germination tests. However, for this pathogen it is more practical and more reliable to use a mycelial growth test, since the radial growth of the colony is very fast $(7-8 \mathrm{~cm}$ in $5 \mathrm{~d}$ at $25^{\circ} \mathrm{C}$ ). Thus, it is easier and more comfortable to measure this radial growth with a ruler than to measure the hyphal growth with a micrometer, especially because this hypha is not straight but mostly curved. Nevertheless, this method requires making single-spore isolations.

\section{Starting material}

The protocol requires banana fruit, as mentioned in the materials and methods part below.

\section{Time estimation}

The time necessary to achieve the method is as follows:

- banana sampling: 30 min (transportation to the field is not included),

- banana ripening for anthracnose lesion development: 10-20 d,

- agar plate preparation: 1-h preparation, 3-h autoclave, $1 \mathrm{~h}$ for fungicide stock solution preparation and pouring media into petri dishes,

- single-spore isolation: 3 h for 30 strains,

- transfer of strains to fungicide-amended and control media: $45 \mathrm{~min}$ (30 strains, 1 control and 1 fungicide concentration),

- incubation of plates: $3 \mathrm{~d}$,

- radial growth evaluation: $15 \mathrm{~min}$ (30 strains, 1 control and 1 fungicide concentration),

- data processing: $30 \mathrm{~min}$ to $1 \mathrm{~h}$.

\section{Expected results}

We obtain (a) for antimitotic products, the percentage of resistant strains in the population analysed; (b) for SBI (Sterol Biosynthesis Inhibitor) fungicides, the variation and distribution of the isolates' sensitivity within the population analysed according to their level of radial growth reduction by the fungicide (EC50).

\section{Materials and methods}

\subsection{Laboratory materials}

The protocol requires: boxes and perforated plastic bags for fruit conservation, a controlled environment cabinet regulated at $25^{\circ} \mathrm{C}$, agar, sterile plastic petri dishes $(90 \mathrm{~mm}$ in diameter), an autoclave, fungicide preparations with known concentration, ethanol, chloramphenicol, $0.45-\mu \mathrm{m}$ filters, micropipettes, and a stereomicroscope.

\subsection{Protocols}

\section{Banana sampling and anthracnose lesion development}

- Step 1. Fruit sample preparation

- Collect 50 fruits. Note: fruits should be collected in a packing station before the postharvest fungicide treatment. In order to obtain more anthracnose lesions, it is advised to collect fruits on bunches that were not covered with a plastic sleeve during their growth [2].

- Bruise fruits in order to induce a faster development of large anthracnose lesions. For this purpose, use a rounded rod and bruise the fruit in several parts by exerting a pressure on the fruit skin with the rounded extremity of the rod. Note: most contaminations occur at the apex of the fruit where it is advised to make more injuries.

- Step 2. Anthracnose lesion development - Store the fruits in a box, inside a plastic perforated bag, to avoid their desiccation. Note: plastic bags must be perforated to prevent the modification of the atmosphere, which would slow down fruit ripening. 
- Transfer fruits into a controlled environment cabinet regulated at $25^{\circ} \mathrm{C}$ until they are ripe and anthracnose lesions are well formed (10-20 d). Caution: the relative humidity should not go below 85\%. Do not use ethylene in order to hasten fruit ripening, since this treatment could induce the development of lesions caused by other non-pathogenic Colletotrichum species [3].

\section{Agar plate preparation}

- Step 3. Media and fungicide solution preparation

- Prepare PDA media (potato extract $4 \mathrm{~g}$, glucose $20 \mathrm{~g}$, agar $15 \mathrm{~g}$ ).

- Prepare a stock solution of chloramphenicol in ethanol $\left(100 \mathrm{mg} \cdot \mathrm{mL}^{-1}\right)$ and add $1 \mathrm{~mL}$ of this solution to $1 \mathrm{~L}$ of the medium after autoclaving.

- Prepare agar + chloramphenicol plates (agar $30 \mathrm{~g} \cdot \mathrm{L}^{-1}$, chloramphenicol $100 \mathrm{mg} \cdot \mathrm{L}^{-1}$ ) for single-spore isolations.

- Prepare agar plates (30 g agar $\cdot \mathrm{L}^{-1}$ ).

- Prepare fungicide-amended agar plates (30 $\mathrm{g} \cdot \mathrm{L}^{-1}+$ the necessary amount of the fungicide to reach the correct concentration).

Note: fungicides should be added after autoclaving. Stock solutions are prepared in order to add a volume of $500-1000 \mu \mathrm{L}$ of fungicide solution for $1 \mathrm{~L}$ of final amended agar media. If the fungicide is miscible in alcohol, add directly the necessary amount of stock solution before pouring onto plates. If the fungicide is miscible in water, filter the stock solution through a $0.45-\mu \mathrm{m}$ sieve before adding the fungicide to the agar medium. Examples of fungicide concentrations commonly used are: thiabendazole $\left(1 \mathrm{mg} \cdot \mathrm{L}^{-1}\right)$, bitertanol or other SBI fungicides $\left[(0.001,0.01,0.1\right.$ or 1$\left.) \mathrm{mg} \cdot \mathrm{L}^{-1}\right]$.

Caution: fungicide-amended agar plates should not be conserved for more than one week.

\section{Single-spore isolation}

\section{- Step 4}

Select 30 fruits bearing a sporulating anthracnose lesion (conidia are formed in pinksalmon-coloured acervuli).

- Step 5

For each fruit, transfer and spread a small part of the pink-salmon spore mass over an agar + chloramphenicol plate.

- Step 6

Incubate at $25-30{ }^{\circ} \mathrm{C}$ for $3-4 \mathrm{~h}$ to initiate conidial germination.

- Step 7

Under a stereomicroscope pick up single germinated spores and transfer them to PDA plates. Note: only one strain per fruit is conserved, so that the final sample constitutes 30 single-spore strains from 30 different fruits.

\section{Colony radial growth test}

- Step 8

Three to four days after the single-spore isolation, remove a $4-\mathrm{mm}^{2}$ plug from the edge of the colony and transfer it to non-amended agar media (control). Repeat the operation for each fungicide concentration tested.

- Step 9

Store the plates at $25^{\circ} \mathrm{C}$ for $3 \mathrm{~d}$.

- Step 10

For each strain, measure the diameter of the colony $(\mathrm{mm})$ with a ruler on pure agar $\left(\mathrm{L}_{\mathrm{Col}}\right.$ ony $)$ and on fungicide-amended agar $\left(\mathrm{L}_{\text {fun- }}\right.$ gicide).

\section{Data analysis}

- Step 11

For antimitotic products (thiabendazole), calculate the percentage of resistant strains on the whole sample (30 strains). Caution: some isolates grow only slightly on thiabendazole $(2-3 \mathrm{~mm}$ ) and should not be considered as resistant. Only isolates with a growth superior to $50 \%$ of the control should be considered as resistant.

- Step 12

Calculation for SBI products (bitertanol):

(a) Calculations for the concentration $0.1 \mathrm{mg} \cdot \mathrm{L}^{-1}$.

- Calculate the growth inhibition (GI) for each fungicide concentration: GI $=[1-$ ( $\left.\left.\mathrm{L}_{\text {fungicide }} / \mathrm{L}_{\text {colony }}\right)\right] \times 100$.

- Determine, for each fungicide concentration, the distribution of sensitivity for each strain using the following growth inhibition classes: [0-10[, [10-20[, [20-30[, [30-40[, 
[40-50[, [50-60[, [60-70[, [70-80[, [80-90[ and [90-100].

- Calculate the frequency of strains in each growth inhibition class and make a graphic representation of this distribution.

- Compare this distribution with that obtained for wild strains from the unsprayed reference area. Particularly, calculate the percentage of classes not represented (NRC) in the untreated area population (low inhibition classes), as well as the mean growth inhibition (MGI). A statistical analysis of the distribution of the two populations will show whether the distribution in the fungal population in contact with the fungicide is different from that of the reference population.

(b) Calculations for a wide range of concentrations $\left[(0.001\right.$ to 1$\left.) \mathrm{mg} \cdot \mathrm{L}^{-1}\right]$.

- For each concentration, determine the GI of each strain. Calculate the average of GI for the population.

- Determine the relation: [GI/fungicide concentration] (graphic representation, model).

- Determine the concentration inducing a $50 \%$ growth inhibition (EC50)

\subsection{Troubleshooting}

Two main problems can occur:

(a) Very few lesions are observed on ripe fruits and it is not possible to obtain 30 isolates from the sample of 50 fruits: initial levels of inoculum are too low.
Solution: harvest fruits from bunches that were not covered with a plastic sleeve and from badly-kept banana plots (poor sanitation practices). Sampling is better in the rainy season.

(b) Fruits do not ripen properly and anthracnose lesions do not develop: humidity inside the room is too low or $\mathrm{CO}_{2}$ is too high.

Solution: take care that the plastic bag is perforated and that the humidity inside the room is not low.

\section{References}

[1] De Lapeyre de Bellaire L., Dubois C., Distribution of thiabendazole-resistant Colletotrichum isolates from Guadeloupe banana plantations, Plant Dis. 81 (1997) 1378-1383.

[2] De Lapeyre de Bellaire L., Chillet M., Dubois C., Mourichon X., Importance of different sources of inoculum and dispersal methods of conidia of Colletotrichum musae, the causal agent of banana anthracnose, for fruit contamination, Plant Pathol. 49 (2000) 782 790.

[3] De Lapeyre de Bellaire L., Bio-écologie de Colletotrichum musae (Berk. \& Curt.) Arx, agent de l'anthracnose des bananes, dans les conditions tropicales humides de la Guadeloupe, thèse, Univ. Paris-Sud, Orsay, France, 1999, $100 \mathrm{p}$ 